\title{
Korea-Mexico Economic Relationship and FTA
}

\author{
Oh-seok Hyun
}

\begin{abstract}
During the last 20 years trade between Korea and Mexico has increased steadily, reaching $\$ 2.8$ billion in 2003. This trade expansion will be further accelerated with the increase in intra-industry trade in the future. Mexico's chronic trade deficit against Korea, which is attributed to Korea's increasing investment in Mexico, has rather contributed to Mexico's exports to the American region.

As Mexico expands its FTA networks, Korean companies are having difficulties in accessing the Mexican market. Considering this situation and the economic benefits of a Korea-Mexico FTA for both countries, we should first expand cooperation between private sectors, which is expected to facilitate a formal discussion on the Korea-Mexico FTA.
\end{abstract}

Keywords: Mexico, Trade, Deficit, Investment, FTA

\section{I . INTRODUCTION}

Korea and Mexico, which have maintained their close political and economic relationship ever since the establishment of the Korean government, have several points in common. The economic and trade scale of the two countries and the ratio of their economy's dependency on foreign trade is similar. Both nations are members of the OECD, but are still regarded as developing countries with a middle-scale economy. In this regard, past experiences and future strategies to reach the rank of an advanced country could have positive implications for each nation. Moreover, there would be much room for mutual cooperation.

In addition, since Korea is adjacent to the biggest market, China, and Mexico to the USA, the biggest economy in the world, a cooperative relationship could establish a significant foothold for both countries to enter North America and East Asia, respectively. This mutual relationship between the two countries would be realized by a Korea-Mexico FTA. In other words, the Korea-Mexico FTA could not only drive the expansion of trade and investment between the two nations but also help them advance into markets of their interest.

I will now take a look at the mutual trade and investment between the two countries before discussing a Korea-Mexico FTA. Then, I will examine Mexico's

\footnotetext{
* Director, Trade Research Institute, Korea International Trade Association, Trade Tower Rm. 4701, World Trade Center, Gangnam-Gu, Seoul 135-729, Korea

Tel: +82 26000 5215, fax: +82 26000 5170, E-mail: oshyun@kita.net
} 
FTA policy and the difficulties and obstacles facing Korean exporters and companies in the Mexican market. The progress of the discussions on a Korea-Mexico FTA until now, its economic effects, and the task of promoting the Korea-Mexico FTA will be discussed in the latter part of my paper.

\section{TRENDS IN TRADE BETWEEN KOREA AND MEXICO}

\section{Overview}

Trade between Korea and Mexico has steadily increased since the two countries concluded diplomatic relations in 1962. After the nations record $\$ 100$ million in trade in 1980, this increased on a large scale due to favorable conditions in the world economy and vigorous advances into the world market. Although Mexico's economic crisis in 1994 and Korea's in 1997 shrank trade between the two countries, both exports and imports are recently seen to be on the rise.

In the middle of 1999, Korea's exports to Mexico increased to 2 billion dollars for the first time, and amounted to 2.5 billion dollars in 2003. During the first quarter of 2004, Korea's exports to Mexico increased 23.3\% year-on-year to 690 million dollars. On the other hand, Korea's imports from Mexico, though fluctuating from time to time, have recently seen a rapid growth. Korea's imports from Mexico rose $53.0 \%$ and $29.6 \%$ respectively in 1999 and 2000 , but declined in the following year due to a domestic economic slowdown. In 2003, Korea's imports from Mexico recovered by two digits and increased $61.7 \%$ during the first three months of this year.

Korea recorded a trade deficit with Mexico until 1987, but the deficit has turned into a surplus since 1988. Korea's trade surplus with Mexico has steadily expanded, amounting to $\$ 2$ billion in 2000 and has remained at the same level since then.

Table 1. Korea's trade with Mexico

\begin{tabular}{c||r|r|r|r|r|r|r}
\hline \multicolumn{1}{c||}{} & \multicolumn{2}{c|}{ Exports } & \multicolumn{2}{c|}{ Import } & \multicolumn{2}{c}{ Balance } & \multicolumn{2}{c}{ Trade } \\
\cline { 2 - 8 } & Amount & Growth rate* & Amount & Growth rate* & Amount & Amount & Growth rate* \\
\hline \hline 1995 & 941 & -27.0 & 307 & 34.2 & 634 & 1,248 & -17.8 \\
\hline 1996 & 1,191 & 26.5 & 408 & 33.1 & 783 & 1,599 & 28.1 \\
\hline 1997 & 1,471 & 23.5 & 344 & -15.7 & 1,127 & 1,815 & 13.5 \\
\hline 1998 & 1,405 & -4.5 & 191 & -44.6 & 1,214 & 1,596 & -12.1 \\
\hline 1999 & 2,017 & 43.6 & 292 & 53.0 & 1,725 & 2,309 & 44.7 \\
\hline 2000 & 2,391 & 18.6 & 378 & 29.6 & 2,013 & 2,769 & 19.9 \\
\hline 2001 & 2,149 & -10.1 & 267 & -29.5 & 1,882 & 2,416 & -12.7 \\
\hline 2002 & 2,231 & 3.8 & 295 & 10.8 & 1,935 & 2,526 & 4.6 \\
\hline 2003 & 2,455 & 10.0 & 334 & 13.0 & 2,121 & 2,789 & 10.4 \\
\hline $04.1 Q$. & 688 & 23.3 & 107 & 61.7 & 580 & 795 & 27.4 \\
\hline
\end{tabular}

* year-on-year growth rate

Source : KITA 
Despite the geographical distance between the two countries, both Korea and Mexico have been ranked fairly high among each other's trade partners. In 2003, Mexico was the 19th largest market for Korea's exports, the 43rd for imports and the 26th for trade.

It is true that Mexico's comparative significance in Korea's trade has declined a little compared to the past ten years, but this is due to the fact that trade between Korea and ASEAN countries rose at a higher speed than that between Korea and Mexico during that time. On the other hand, Korea became a more important market for Mexico. Korea is currently the 29th largest market for Mexico's exports, up from 41st in 1993, and the 5th market for Mexico's imports, up from 9th, which means that Korea is now Mexico's 6th largest trade partner.

Table 2. Korea and Mexico's mutual significance in trade

\begin{tabular}{c||c|c|c}
\hline \multicolumn{1}{c||}{} & & $\mathbf{1 9 9 3}$ & $\mathbf{2 0 0 3}$ \\
\hline \hline \multirow{2}{*}{$\begin{array}{c}\text { Mexico's position } \\
\text { in Korea's trade }\end{array}$} & Trade & 25 th & 26th \\
\cline { 2 - 4 } & Exports & 17 th & 19th \\
\cline { 2 - 4 } & Imports & 42nd & 43rd \\
\hline \multirow{2}{*}{$\begin{array}{c}\text { Korea's position } \\
\text { in Mexico's trade }\end{array}$} & Trade & 10 th & 6th \\
\cline { 2 - 4 } & Exports & $41 \mathrm{st}$ & 5th \\
\cline { 2 - 4 } & Imports & 9 th & \\
\hline
\end{tabular}

\footnotetext{
"Based on statistics during 2003 January $\sim$ October
}

Source : KITA, and the IMF

Korea's share in the Mexican import market was ranked 5th following the US, China, Japan and Germany, and followed by Brazil, Spain and Canada. Though Korea is only the 29th market for Mexico's exports, Korea is ahead of Peru, Argentina, and some European countries such as Portugal, Sweden and Denmark.

Table 3. Trends in Mexico's trade by major countries

(\$100million, \%)

\begin{tabular}{r||c|r|r|r|r|r|r}
\hline \multicolumn{1}{c||}{} & \multicolumn{4}{c|}{ 2002 } & \multicolumn{3}{c}{ 2003(Jan. Oct.) } \\
\cline { 2 - 8 } & & Export & Import & Balance & Export & \multicolumn{1}{c}{ Import } & Balance \\
\hline \hline 1 & USA & 1,430 & 1,172 & 258 & 1,057 & 886 & 172 \\
\hline 2 & Canada & 28 & 49 & -21 & 54 & 22 & 32 \\
\hline 3 & Germany & 12 & 67 & -54 & 13 & 56 & -43 \\
\hline 4 & Japan & 5 & 103 & -98 & 11 & 56 & -45 \\
\hline 5 & China & 5 & 69 & -64 & 6 & 60 & -55 \\
\hline 6 & Korea & 2 & 43 & -41 & 2 & 41 & -39 \\
\hline 7 & Spain & 14 & 24 & -10 & 13 & 22 & -9 \\
\hline 8 & Brazil & 5 & 28 & -23 & 5 & 26 & -22 \\
\hline 9 & Malaysia & 1 & 22 & -21 & 1 & 21 & -21 \\
\hline 10 & Italy & 2 & 24 & -22 & 2 & 19 & -17 \\
\hline & Total & 1,608 & 1,855 & -248 & 1,263 & 1,412 & -149 \\
\hline
\end{tabular}

Source : DOTS, and the IMF 
Regarding shares of Mexico's import market by countries, the US has stood unchallenged by other nations, securing $62.7 \%$ during the first 10 months in 2003 , and Korea recorded 2.9\% during the same period. During 1993 to 2003, the shares of the USA, Japan and Germany declined respectively on a small scale, but those of China and Korea increased. Korea's share rose from $1.9 \%$ to $2.9 \%$ in 2003 up from $1.0 \%$ in 1993.

Figure 1. Major countries' shares in the Mexican market

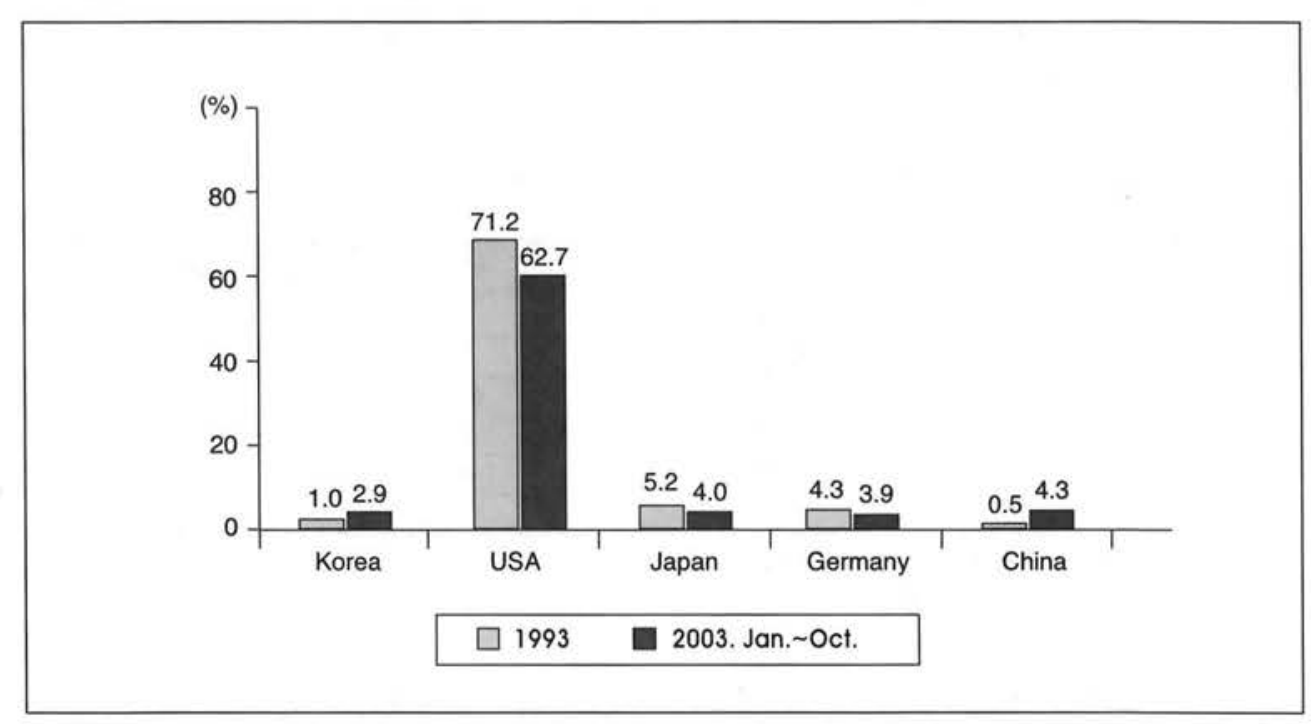

Figure 2. Trend of Korea's shares in the Mexican market

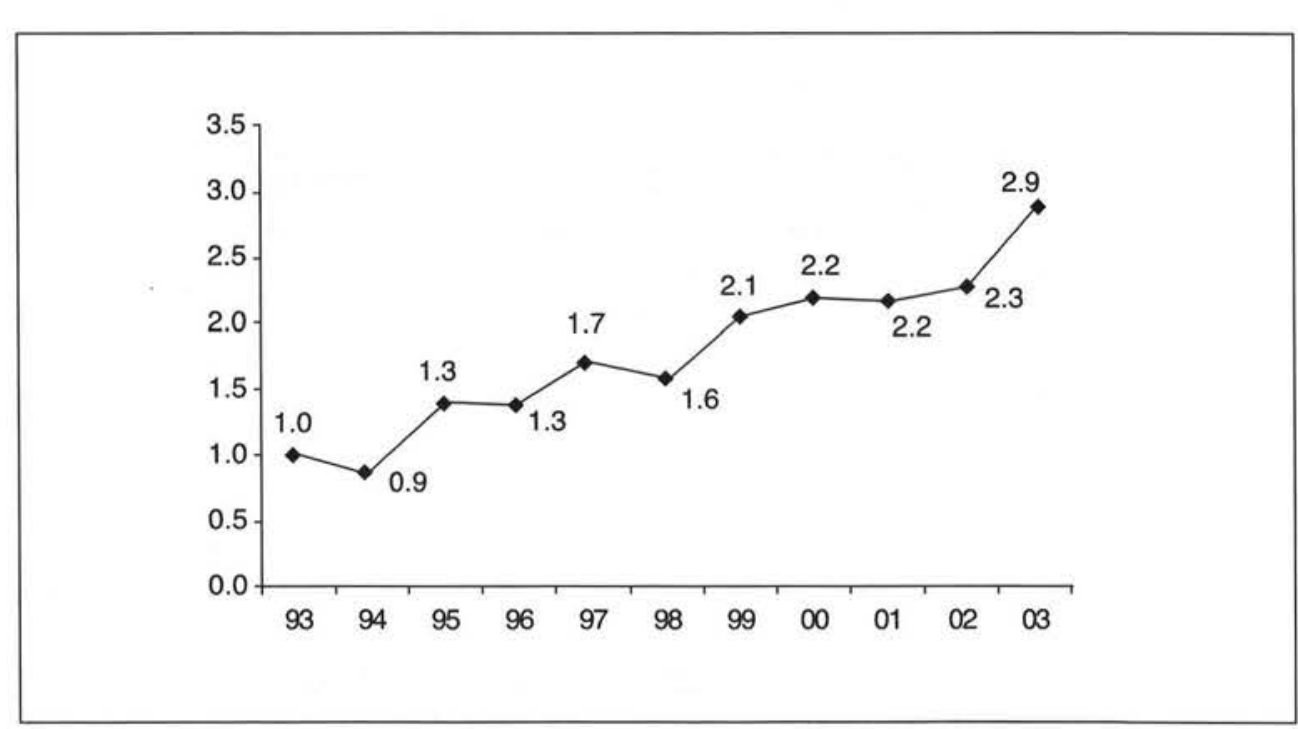




\section{Trends in trade by item}

\subsection{Structure by item}

Regarding the trade structure between Korea and Mexico, it appears that while the share of light manufactured goods and raw materials is decreasing, that of heavy industries, especially IT products, and capital goods is expanding. In 2003, the share of heavy industrial goods among Korea's total exports to Mexico reached $91.0 \%$, up from $65.3 \%$ ten years earlier. The share of IT products doubled from $16.3 \%$ to $40.5 \%$ during the same period.

The ratio of raw materials and consumer goods among Korea's total exports was higher in 1993, but the share of capital goods was the highest reaching $43.8 \%$ in 2003. This means that a large portion of Korea's exports to Mexico is used for Mexico's exports and domestic industrial development.

The share of Korea's imports of IT products from Mexico also rose from $5.1 \%$ in 1993 to $38.6 \%$ in 2003. In 1993, imports of raw materials took up $81.6 \%$ of Korea's total imports from Mexico, but capital goods secured $44.9 \%$ and consumer goods rose on a large scale to $20.1 \%$ in 2003 . This shows that the pattern of Korea's imports from Mexico has changed from mainly importing raw materials for simple manufacturing to importing more value-added products such as capital and consumer goods.

Table 4. Korea's Export to and import from Mexico by sector

\begin{tabular}{l||r|r|r|r}
\hline \multicolumn{1}{c||}{} & \multicolumn{2}{c}{ Exports } & \multicolumn{2}{c}{ Import } \\
\cline { 2 - 5 } & 1993 & \multicolumn{1}{c}{2003} & 1993 & \multicolumn{1}{c}{2003} \\
\hline \hline \multicolumn{1}{c||}{ Primary commodition, \%) } & $0.4(0.4)$ & $0.6(0.2)$ & $2.9(18.4)$ & $5.2(15.6)$ \\
\hline Light manufactures & $34.3(34.4)$ & $21.6(8.8)$ & $1.4(8.9)$ & $2.2(6.6)$ \\
\hline Heavy manufactures & $65.1(65.3)$ & $223.4(91.0)$ & $11.5(72.8)$ & $25.9(77.5)$ \\
\hline (IT products) & $16.3(16.3)$ & $99.4(40.5)$ & $0.8(5.1)$ & $12.9(38.6)$ \\
\hline Raw materials & $30.4(30.5)$ & $49.1(20.0)$ & $12.9(81.6)$ & $11.7(35.0)$ \\
\hline Capital goods & $20.4(20.5)$ & $107.6(43.8)$ & $1.2(7.6)$ & $15.0(44.9)$ \\
\hline Consumer goods & $49.0(49.1)$ & $88.6(36.1)$ & $1.6(10.1)$ & $6.7(20.1)$ \\
\hline Total & $99.7(100.0)$ & $245.5(100.0)$ & $15.8(100.0)$ & $33.4(100.0)$ \\
\hline \multirow{2}{*}{$*():$ share } & & & & \\
Source : KITA & & & &
\end{tabular}

\subsection{Current status of imports and exports by major item}

Korea's major export items to Mexico have seen a great change over the past ten years. Leading goods were concentrated on consumer products ten years ago, but now they consist of parts and components used for Mexico's production and exports. In 1993, Korea's major export goods were color TVs, textiles, VCRs, and radio cassettes, but now these are capital goods such as computer monitors and parts, color TVs, wireless phones and parts, cathode ray-tubes, and parts of electrotubes. It was 
estimated that more than half of Korea's exports to Mexico in 2003 consisted of parts and components with which Korean companies operating in Maquiladora used to produce computers, TVs, refrigerators, and washing machines. Textiles like polyester and knitted fabrics are also Korea's major exports, which are very popular among Mexican clothing manufacturers exporting to the USA.

Motor vehicles are also a major export product, but as Mexico imposes a high tariff rate of $50 \%$ on vehicles made in non-FTA partner countries like Korea, it is substantially difficult for Korean auto companies to enter the Mexican market by themselves. This is believed to hamper mutual trade as a whole. Auto vehicles made in Korea were not allowed to enter into the Mexican market because the modernization and promotion of the auto industry banned imports from countries which didn't produce auto vehicles within Mexico. Though this measure was eliminated at the end of 2003, Mexico, instead, chose to raise tariff rates on imported auto vehicles, which serves as a huge barrier to Korean auto companies.

Korea's auto exports to Mexico are now on the rise, but it is due to the fact that foreign companies like Daimler-Chrysler and GM are importing small cars made in Korea. Since November of 2000, Daimler-Chrysler has imported Atoz and small trucks from Hyundai, consuming its own import quota in order to compete with GM and Ford. Daimler-Chrysler has been expanding the range of cars from Hyundai since 2003. GM also began to import Matiz from GM Daewoo from the third quarter of 2003.

Table 5. Korea's major export goods to Mexico

\begin{tabular}{|c|c|c|c|c|c|c|}
\hline & \multicolumn{3}{|c|}{1993} & \multicolumn{3}{|l|}{2003} \\
\hline & Products & Amount & Share & Products & Amount & Share \\
\hline 1 & Color TVs & 255 & 25.6 & Monitors & 291 & 11.9 \\
\hline 2 & Polyester fabrics & 98 & 9.8 & Color TVs & 275 & 11.2 \\
\hline 3 & Cathode-ray tubes & 95 & 9.5 & Wireless phones & 190 & 7.7 \\
\hline 4 & $\begin{array}{l}\text { Regenerated staple } \\
\text { fiber fabrics }\end{array}$ & 40 & 4.0 & Parts of computers & 129 & 5.3 \\
\hline 5 & VCRs & 34 & 3.4 & Synthetic resin & 119 & 4.8 \\
\hline 6 & Radio cassettes & 32 & 3.2 & Cathode-ray tubes & 116 & 4.7 \\
\hline 7 & Monitors & 29 & 2.9 & Passenger cars & 111 & 4.5 \\
\hline 8 & Refrigerators & 28 & 2.8 & $\begin{array}{l}\text { Parts of wireless } \\
\text { communication apparatus }\end{array}$ & 70 & 2.9 \\
\hline 9 & Sports footwear & 28 & 2.8 & Parts of electrotubes & 68 & 2.8 \\
\hline \multirow[t]{2}{*}{10} & Tires & 27 & 2.7 & Glass bulbs & 67 & 2.7 \\
\hline & Total & 997 & 100.0 & Total & 2,455 & 100.0 \\
\hline
\end{tabular}

Source : KITA

Among Korea's major imported goods from Mexico, imports of IT products such as semiconductors, wire and wireless communication apparatus, and computers are rapidly increasing. In particular, imports of computers, communication apparatus, and semiconductors are recently rising at a high speed. This is because major electronic companies worldwide, including Korean ones, are increasing their investment in 
Mexico. In the case of motor vehicles, Korea now imports assembled vehicles by Daimler-Chrysler and Volkswagen in Mexico.

Table 6. Korea's major import goods from Mexico

\begin{tabular}{|c|c|c|c|c|c|c|}
\hline & \multicolumn{3}{|l|}{1993} & \multicolumn{3}{|l|}{2003} \\
\hline & Products & Amount & Share & Products & Amount & Share \\
\hline 1 & $\begin{array}{l}\text { Synthetic fiber raw } \\
\text { materials }\end{array}$ & 47 & 29.7 & $\begin{array}{l}\text { Integrated circuit } \\
\text { Semiconductors }\end{array}$ & 38 & 11.4 \\
\hline 2 & $\begin{array}{l}\text { Semi-finished products } \\
\text { of steel }\end{array}$ & 27 & 17.1 & $\begin{array}{l}\text { Semi-finished } \\
\text { products of steel }\end{array}$ & 33 & 9.9 \\
\hline 3 & Jet fuel or kerosene & 12 & 7.6 & Cable electrical transmissions & 25 & 7.5 \\
\hline 4 & Salt & 10 & 6.3 & $\begin{array}{l}\text { Parts of wireless } \\
\text { communication apparatus }\end{array}$ & 19 & 5.7 \\
\hline 5 & Acetate filament yarn & 8 & 5.1 & Salt & 17 & 5.1 \\
\hline 6 & Coffee & 6 & 3.8 & Pharmaceuticals & 15 & 4.5 \\
\hline 7 & Zinc ore & 5 & 3.2 & Transistors or diodes & 12 & 3.6 \\
\hline 8 & $\begin{array}{l}\text { Microphones and } \\
\text { headphones }\end{array}$ & 4 & 2.5 & $\begin{array}{l}\text { Other processed fishery } \\
\text { products }\end{array}$ & 12 & 3.6 \\
\hline 9 & Transistors or diodes & 3 & 1.9 & Acetate filament yarn & 11 & 3.3 \\
\hline \multirow[t]{2}{*}{10} & Silver & 3 & 1.9 & Passenger cars & 10 & 3.0 \\
\hline & Total & 158 & 100.0 & Total & 334 & 100.0 \\
\hline
\end{tabular}

Source : KITA

\section{Differences between Korean and Mexican trade statistics}

\subsection{Differences in trade statistics}

While Korea's trade statistics show that Korea recorded a trade surplus of about $\$ 2$ billion in its trade with Mexico, according to Mexico's statistics, this surplus was reported to be about $\$ 4$ billion, almost twice the amount reported in Korea.

The statistical differences between Korea's exports to Mexico and Mexico's imports from Korea is what led to such a discord between the trade balances in the two countries. 
Table 7. Trade between Korea and Mexico

(\$ billion)

\begin{tabular}{|c|c|c|c|}
\hline \multicolumn{4}{|c|}{$<$ Korea's statistics $>$} \\
\hline Year & Exports to Mexico & Imports from Mexico & Trade balanc \\
\hline 2001 & 2.15 & 0.27 & 1.88 \\
\hline 2002 & 2.23 & 0.30 & 1.94 \\
\hline 2003 & 2.46 & 0.33 & 2.12 \\
\hline \multicolumn{4}{|c|}{$<$ Mexico's statistics $>$} \\
\hline Year & Exports to Korea & Imports from Korea & Trade balance \\
\hline 2001 & 0.29 & 3.53 & -3.24 \\
\hline 2002 & 0.19 & 3.91 & -3.73 \\
\hline 2003 & 0.10 & 4.11 & -4.02 \\
\hline
\end{tabular}

Source : KITA, and the Banko de Mexico

\subsection{Statistical differences by product}

The statistical differences in trade are particularly large in products such as computer parts, semiconductors, and color TV components. By 6 digit HS code, the biggest difference is $\$ 376$ million in computer parts (HS 847330). Monolithic integrated circuits (HS 854230), data display tubes (HS 854040), and hybrid integrated circuits (HS 854240) show a difference of about \$100 200 million.

It is assumed that these differences are due to the fact that there are some products made in Korea that are exported to Mexico via the USA or other neighboring countries. In the case of computer parts (HS 847330), Korea's exports to Mexico are $\$ 119$ million, but Mexico’s imports from Korea amount to \$566 million. The difference between the two is $\$ 376$ million.

These differences seem to arise because some products that Korea exports to the USA are re-exported to Mexico. In this case, Mexico regards Korea, not the USA, as an exporting country of the products because they are made in Korea. This assumption is more probable in that while the US's exports to Mexico are \$2.53 billion, Mexico's imports from the US are $\$ 1.39$ billion. 
Table 8. Differences between Korea's exports and Mexico's imports by product (2002)

\begin{tabular}{|c|c|c|c|c|c|}
\hline & & & & & illion, \%) \\
\hline $\begin{array}{c}\text { HS } \\
\text { Code }\end{array}$ & Products & $\begin{array}{l}\text { Mexico's } \\
\text { im. from } \\
\text { Korea(a) }\end{array}$ & $\begin{array}{c}\text { Korea's } \\
\text { ex. to } \\
\text { Mexico(b) }\end{array}$ & $\begin{array}{l}\text { Differences } \\
\text { btw. a \& b } \\
\text { (c) }\end{array}$ & $\begin{array}{l}c / a \\
(\%)\end{array}$ \\
\hline Total & - & 3,910 & 2,231 & $1,679(100.0)$ & 42.9 \\
\hline 84 & Nuclear reactors, boilers, etc. & 1,115 & 610 & $505(30.1)$ & 45.3 \\
\hline 847330 & $\begin{array}{l}\text { Parts and accessories for } \\
\text { automatic data processing }\end{array}$ & 566 & 191 & $376(22.4)$ & 66.3 \\
\hline 847170 & Storage units & 40 & 10 & $30(1.8)$ & 74.7 \\
\hline 847510 & $\begin{array}{l}\text { Machines for assembling } \\
\text { electronic and electric lamps }\end{array}$ & 28 & 0 & $28(1.7)$ & 100.0 \\
\hline 85 & Electric machinery and parts & 1,615 & 824 & $791(47.1)$ & 49.0 \\
\hline 854230 & Monolithic integrated circuits & 184 & 4 & $179(10.7)$ & 97.6 \\
\hline 854040 & Display Tubes & 145 & 0 & $145(8.7)$ & 100.0 \\
\hline 854240 & Hybrid integrated circuits & 130 & 0 & $130(7.8)$ & 99.9 \\
\hline 854213 & Metal oxide semiconductors & 92 & 1 & $91(5.4)$ & 98.7 \\
\hline 854011 & $\begin{array}{l}\text { Cathode-ray television } \\
\text { picture tubes, color }\end{array}$ & 135 & 88 & $48(2.8)$ & 35.3 \\
\hline 853400 & Printed circuits & 64 & 21 & $43(2.6)$ & 67.5 \\
\hline 853690 & $\begin{array}{l}\text { Electrical apparatus for } \\
\text { Switching }\end{array}$ & 25 & 1 & $24(1.4)$ & 96.3 \\
\hline
\end{tabular}

( ): ratio of total trade difference between Mexico's imports from Korea and Korea's exports to Mexico Source : UNCTAD, and PC-TAS

Considering differences between Mexico's imports from major trade partners, such as China and Japan, and their exports to Mexico, the difference between Korea's exports and Mexico's imports is relatively small.

Table 9. Differences between Mexico's imports from major trade partners and their exports to Mexico

\begin{tabular}{l||c|c|c|c}
\hline & $\begin{array}{c}\text { Exports to Mexico } \\
\text { (a) }\end{array}$ & $\begin{array}{c}\text { Mexico's imports } \\
\text { (b) }\end{array}$ & $\begin{array}{c}\text { Differences } \\
\text { (c) }\end{array}$ & $\begin{array}{c}\mathbf{c} / \mathbf{b} \\
(\mathbf{\%})\end{array}$ \\
\hline \hline America & 86.08 & 106.90 & 20.82 & 19.5 \\
\hline Japan & 3.78 & 9.35 & 5.57 & 59.5 \\
\hline China & 2.86 & 6.27 & 3.41 & 54.4 \\
\hline Canada & 1.54 & 4.48 & 2.94 & 65.6 \\
\hline Korea & 2.23 & 3.91 & 1.68 & 43.0 \\
\hline
\end{tabular}

(a): Each country's own statistics (PC-TAS), (b): Mexico's statistics (Banko de Mexico) 


\section{KOREA-MEXICO INVESTMENT TREND}

\section{Investment Trend}

Since 1980 there have been a total of 82 cases, amounting to $\$ 280$ million, of Korean investment in Mexico. Last year, there were 8 cases amounting to $\$ 7.4$ million, which is a big decline, but this is following a trend considering that Korea's overseas investments have in general dropped since 2000. Also, Korean investment in Mexico by industry tends to be concentrated in the manufacturing and construction industries. By 2003 standards, with an investment of \$6 million in manufacturing and $\$ 500,000$ in construction, these two industries occupy $96.7 \%$ of Korea's total investment in Mexico.

Table 10. Korea's investment in Mexico

\begin{tabular}{c||r|r|r|r|r}
\hline \multicolumn{1}{c||}{} & \multicolumn{1}{c|}{ (case, \$, \%) } \\
\hline \hline Investment & 15 & \multicolumn{1}{c|}{$\mathbf{2 0 0 1}$} & \multicolumn{1}{c|}{$\mathbf{2 0 0 2}$} & \multicolumn{1}{c|}{$\mathbf{2 0 0 3}$} & $\mathbf{1 9 8 0 ~ 2 0 0 3}$ \\
cases & $(150.0)$ & $(-86.7)$ & $(350.0)$ & $(-11.1)$ & 83 \\
\hline Invested & 21,316 & 17,870 & 42,267 & 7,361 & 283,741 \\
Amount & $(139.8)$ & $(-16.2)$ & $(136.5)$ & $(-82.6)$ & \\
\hline
\end{tabular}

* ( ) : growth rate $(\%)$

Source : The Export-Import Bank of Korea

Mexico's investment in Korea has not shown much stock since its record of \$2.8 million in 1999. There was no stock in 2000, and during 2001 and 2002, there was one investment case per year at $\$ 100,000$ and $\$ 85,000$, respectively. This is very small compared to Korea's investment in Mexico.

Table 11. Mexico's investment in Korea (based on reports)

\begin{tabular}{c|c|c|c|c|c|c|}
\hline & $\mathbf{1 9 9 9}$ & $\mathbf{2 0 0 0}$ & $\mathbf{2 0 0 1}$ & $\mathbf{2 0 0 2}$ & '03.1st 2ndQ. & 1962 2003 \\
\hline \hline $\begin{array}{c}\text { Reported } \\
\text { cases }\end{array}$ & 1 & 0 & 1 & 1 & 0 & 4 \\
\hline $\begin{array}{c}\text { Reported } \\
\text { amount }\end{array}$ & 2,756 & 0 & 100 & 85 & 0 & 2,998 \\
\hline
\end{tabular}

Source : MOCIE 


\section{Cases of investment in Mexico by Korea's leading manufacturers}

It is reported that about 150 Korean companies are currently operating in Mexico and they employ 27,249 Mexican workers. The total value of their investment in Mexico amounts to $\$ 1.5$ billion. $^{\prime}$

Korea's leading manufacturers, such as Samsung Electronics, LG Electronics, and Trigem Computers, are equipped with a mass-production base for LCD TVs, refrigerators, and computers, which are to be exported to North and South American markets. Plans are being made for large-scale investment expansion in the near future. Let's take a closer look at the actual cases.

\section{(1) Samsung Electronics}

Samsung Electronics advanced into Tijuana, Mexico, in 1988 and established a plant (SAMEX) that manufactures color TVs, monitors, PCs, and cellular phones. 2 Starting from 2003, they have completed preparation for mass-production of PDP TVs following LCD TVs, with the capacity of manufacturing a maximum of 100,000 LCD TVs and 100,000 PDP TVs per year.

Also during April, 2003, by establishing a big-scale production base in Quertaro City, in central Mexico, which produces refrigerators and air-conditioners, Samsung Electronics has completed building a plant for electronic home appliances, with a capacity of 500,000 units. They have invested $\$ 50$ million as the first step and are planning to increase investment up to $\$ 300$ million in the next five years.

Samsung Electronics is planning to produce high value-added goods, such as sideby-side refrigerators and drum washing machines in Mexico, which is expected to satisfy needs for high-end goods in North and South America's household electronics market. Currently about $69 \%$ of Samsung Electronic's total revenue of $\$ 2.6$ billion in Mexico comes from its exports to the USA, Canada, and other South American countries. $^{3}$

\section{(2) LG Electronics}

LG Electronics has established a refrigerator manufacturing plant (LGEMM) in Monterrey (April 2000), in the north-east of Mexico, a monitor manufacturing plant (LGEMX) in Mexicali (July 1988), in the north-west of Mexico, and a TV manufacturing plant (LGERS) in Reynosa (January 2000), as well as operating a separate sales corporation (LGEMS) in Mexico City.

The annual production capacity of these manufacturing plants is 1.8 million monitors, 2 million TV's, and 1 million refrigerators. These manufactured goods are exported to North American regions and also South American regions, such as Panama and Columbia as well as sold in Mexico's domestic market. The share of

\footnotetext{
'The figures were provided by the Embassy of Korea in Mexico.

${ }^{2}$ Trade News, 24 April, 2004.

${ }^{3}$ Ibid.
} 
exports among its total revenue is about $50.8 \%$, which amounts to $\$ 1$ billion. ${ }^{4}$

\section{(3) Trigem Computers}

Trigem Computers manufacturing plant (TGMX S.A. DE C.V.) located in Jurez, Mexico, was established in September of 2001, and with 23 production lines, it is capable of producing 2.84 million computers yearly. In particular, Trigem Computers' plant in Mexico is located on the U.S. border, so the amount of time it takes to deliver goods from Korea to the U.S. has been shortened to $2 \sim 4$ days instead of 15 days. This drastically cuts down logistics costs, and it can strengthen services on ODM companies.

With these geographical advantages, within two years of establishing the plant, production has almost tripled, and at present, more than 400,000 orders per month have been made. ${ }^{5}$

\section{EVALUATION AND OUTLOOK OF KOREA-MEXICO'S TRADE-INVESTMENT}

During the last 20 years, trade between Korea and Mexico has increased steadily, and this trend will accelerate even further in the future. The trade scale was only $\$ 100$ million in 1980, but steadily increasing, it went over \$1 billion and \$2 billion in 1992 and 2000 , respectively, and last year it went up to as far as $\$ 2.8$ billion. This expansion in trade between the two countries will be further accelerated with the expansion in intra-industry trade and international competitiveness focused on the IT industry of both countries. Therefore, we can expect that through mutual trade expansion between Korea and Mexico, their position in international trade will become more solid.

In terms of trade balance, compared to Mexico, Korea has undergone a trade deficit until 1987, but after 1988 it has changed to a surplus and this trend has continued. During the early 1990's, Korea's surplus in trade with Mexico was around $\$ 1$ billion, but by 2000 it has expanded to $\$ 2$ billion. However, since 2001 , this figure has remained the same. Lastly, regarding the trade imbalance between the two countries, here are some facts to consider in terms of exports and imports.

First, in terms of export, the reason behind the trade imbalance between the two countries is in large part due to the on-spot investment in Mexico by Korean companies, and major items such as parts and materials contributing greatly to the export expansion and economic development of Mexico. With Korea's chief export items mainly consisting of monitors, computer parts, wireless communications equipment parts, cathode-ray tubes, electron tubes, and so on, it shows that a substantial part of Korea's exports to Mexico are used by companies that have

\footnotetext{
${ }^{4}$ Ibid.

${ }^{5}$ Ibid.
} 
advanced into Maquiladora to export.

For example, in 1993, the main export items were consumer products, such as color TVs, textiles, cathode-ray tubes, VCRs, radio-cassettes, refrigerators, etc., but in 2003, except for color TVs and wireless phones, capital goods such as monitors, computer parts, wireless communications equipment parts, cathode-ray tubes, electron tubes, etc., consisted of much of the export items. Export statistics shows this clearly. In exports to Mexico in 1993, consumer goods took up 49.1\%, but in 2003 this dropped to $36.1 \%$, whereas capital goods doubled from $20.5 \%$ to $43.8 \%$ in the same period.

This can be seen in investment flow, which is contrary to export and import flow. During 1980 2003, there were 83 cases of Korean investment in Mexico, at a rate of $\$ 280$ million, but there were only 4 cases, at a rate of $\$ 3$ million, of Mexico's investment in Korea during 1962 2003. More recently, Korean manufacturers are giving more attention to investing in Mexico. For example, Samsung Electronics has invested \$50 million in Quertaro City, in April of 2003, and is planning to expand its investment scale to $\$ 300$ million in the next 5 years.

The trade imbalance between Korea and Mexico is mainly because of Korea's investment in Mexico, and because of the increase in imports of parts by Korean companies in Mexico that are concentrating more on exports to the North American region and South American region than sales in the Mexican domestic market. Also, considering Mexico's geographical significance bordering between North America and Central and South America, Korean manufacturer's investment into Mexico will increase, and separate from the statistical trade imbalance numbers, Korea's export of parts will contribute to Mexico's economic growth. In this regard, there is a need to look at the trade imbalance between the two countries in multilateral terms, not bilateral terms.

Next, the possibility of expanding Korea's imports from Mexico should be considered, and through this expanded equilibrium in trade should be achieved. Starting from this year, during the first quarter, imports from Mexico have increased $61.7 \%$, three times the growth rate in exports, showing possibilities of achieving expanded equilibrium in trade between both countries. Excluding the years 1997 and 1998 when Korea suffered from the foreign exchange crisis, and 2001 when Korea's economy was stagnant, the growth rate in imports from Mexico, especially, have always exceeded that in exports to Mexico. Also, IT goods are taking up more space as Korea's chief imported items from Mexico, such as semiconductors, wire/wireless communications equipments, computers, and so on, this trend will help the two countries to achieve a trade balance. This is because in international trade, between developing countries, not to mention developed countries, it is expected that Korea's imports of IT goods will increase along with intra-industry trade, intra-firm trade, and expansion trends (OECD 2002). ${ }^{6}$ A good example may be that, recently, where investments (FDI) into Mexico by electronic industries from the world's leading

\footnotetext{
${ }^{6}$ See OECD, Economic Outlook 2002 (Chapter IV. Intra-industry and Intra-Firm Trade and The Internationalizations of Production).
} 
countries, including Korea, have increased, and Daimler Chrysler's and Volkswagon (VW)'s cars have been assembled and produced in Mexico and are being imported to Korea.

The trade between Korea and Mexico has increased steadily, but considering these countries position in international trade and their economic scale, it is not enough. This also means that there are plenty of possibilities of expansion depending on economic cooperation between the two countries. Moreover, for Korea and Mexico to start with a new leap, it is time to stop relying on existing specific regions and to bring change in export markets. From this, in Mexico's view, the fact that Korea can be a key market for expanding exports, not only to North and South America, but to the Northeast Asian region, including Japan, and in Korea's view, the fact that Mexico can be a key market for North American and Central and South American regions, is significant for cooperation measures between the two countries. Therefore, the conclusion of an FTA between these two countries, and actively promoting economic cooperation will encourage expanded equilibrium in trade, as well as mutual direct investment, which I assure will serve as a driving force for the development of both Korea and Mexico.

\section{MEXICO'S PROMOTION OF FTA AND ITS EFFECTS}

\section{Mexico's status on FTA and its FTA policy}

Mexico has concluded more FTAs than any other country in the world, and its FTAs with 31 countries are currently effective. The major countries that Mexico has concluded FTAs with are the USA, Chile, Canada, Colombia, Guatemala, Israel, EU, EFTA, among others, further FTAs with Uruguay and Japan have recently been concluded. Mexico is now under negotiations with Argentina, Mercosur, Singapore and is participating in the FTAA negotiations in which 34 countries over the American continent are involved.

Mexico has emphasized the conclusion of FTAs as the core of its trade policy so far, but last year, the Mexican government announced that, for the time being, it would focus upon on-going FTA negotiations rather than initiating discussions on a new FTA. The ratio of trade between Mexico and its FTA partners now amounts to $86.0 \%$, which means most of its trade is maintained within its FTA networks. Therefore, countries that have not concluded FTAs with Mexico, like Korea, are facing a variety of direct and indirect trade barriers including high tariffs.

\section{Difficulties and barriers facing Korean companies in Mexico}

Fortunately, the overall image of products made in Korea has been quite good in the Mexican market so far. This is primarily due to the marketing efforts of big Korean companies, such as Samsung, LG, and Daewoo. Especially, the image of Korean cellular phone brands, household electronic appliances, computers and monitors, and tiers are very firmly settled among Mexican consumers. For example, 
Samsung secures the 1st position in the CDMA cellular phone market, which occupies $30 \%$ of the whole Mexican cellular phone market. Samsung also holds a $15 \%$ share of television, $18 \%$ of the color monitor market and $28 \%$ of the microwave oven market.

Despite such favorable views of Korean products, most Korean exports to Mexico are confronted with rather high tariffs at a rate between $13 \sim 35 \%$. The tariff rates on some major products are as follows: $20 \sim 30 \%$ on most vehicles, $13 \sim 28 \%$ on textiles, $10 \sim 20 \%$ on electric and electronic goods, and 13 18\% on iron and steel products. As a result, the price competitiveness of Korean products is getting weaker compared to products from the USA, EU, and other countries that have concluded FTAs with Mexico. Moreover, since price competitiveness is the most significant factor in the Mexican market, Korean products, even if they are of high quality and technology, are having a difficult time accessing the market.

From January 2004, Mexico began to raise the tariff rate on vehicles manufactured by non-FTA countries up to $50 \%$, this raise did not apply to vehicles manufactured by FTA partners such as the USA, Canada and EU states, which occupy $60 \%$ of imported vehicles into Mexico. This obviously presents a disadvantage to the import of Korean vehicles. In addition, in case of the tire sector, in which Korean goods are fairly competitive, Mexico has changed its ad valorem duty of $23 \%$ to specific duties and now imposes applied tariffs from $25 \%$ up to $90 \%$ on tires made by non-FTA counterparts including Korea. Tires made by Mexico's FTA partners, however, are still imported duty-free.

\section{The effects of the Japan-Mexico FTA}

The recent conclusion of a Mexico-Japan FTA is expected to worsen Korean exporters' competitiveness and the difficult environment surrounding Korean companies operating in Mexico. According to a report titled "the expected effects of a Mexico-Japan FTA on Korean exporters", which the Trade Research Institute published this year, it was expected that the adverse effects of the Mexico-Japan FTA on Korean exporters would be immense. It was reported that about $22 \%$ of Korea's overall exports to Mexico is competing with or at a comparative disadvantage to Japanese goods. ${ }^{7}$ Therefore, if the Mexico-Japan FTA becomes effective, Korean products with an average tariff of $15 \%$ would be at a disadvantage compared to dutyfree Japanese goods. It would be a major blow to overall exports to Mexico from Korea. This result was also true of a survey targeting Korean exporters that have maintained trade relationships with Mexico. They responded that they expected that their exports to Mexico would decrease more than $10 \%$ due to the Mexico-Japan FTA.

\footnotetext{
${ }^{7}$ Duck-Jin Huh, "The expected effects of a Mexico-Japan FTA on Korean exporters," in Trade Report(March), Seoul: KITA, 2004.
} 


\section{THE KOREA-MEXICO FTA:FEASIBILITIES AND TASKS}

\section{Discussion on a Korea-Mexico FTA}

The first discussion of an FTA between Korea and Mexico began in 1999 when the Mexican ambassador in Korea and the Korean trade minister touched upon the need to examine the possibilities of a Korea-Mexico FTA. In 2000, the plan to promote an FTA between the two countries in three phases was discussed by the Korea-Mexico Joint Economic Commission. In the first phase, the private sectors of the two countries would strengthen their cooperation, then in the second phase, conclude a bilateral investment treaty, and lastly, make a joint study on the possibilities of a Korea-Mexico FTA. In the same year, Korea and Mexico actually concluded their bilateral investment treaty. However, from that time on, there has not been any formal discussions on an FTA between the two countries even though private sectors in both countries have continuously expressed their interest in it.

\section{The economic effects of a Korea-Mexico FTA}

Last year, a report titled "the feasibilities and economic effects of a Korea-Mexico FTA" was published by KIEP in Korea. According to this study, if a Korea-Mexico FTA is concluded, it is expected that while Korea's real GDP would increase $0.01 \%$ in the near term and $0.03 \%$ in the medium to long term, Mexico's would increase $0.02 \%$, and $0.15 \%$, respectively. With regard to welfare, it was analyzed that Korea's welfare would be improved more than Mexico's in the short term, but, in the medium to long term, Mexico's welfare change would amount to 440 million dollars, which would be much bigger than that of Korea. ${ }^{8}$

These figures were computed solely as a result of tariff elimination between the two countries by using the CGE model. Thus, they don't reflect various kinds of dynamic effects, which originate from economies of scale, promotion of competition, expansion of investments, and so on. These factors being taken into consideration, could see the longer-term economic benefits of a Korea-Mexico FTA further extended.

Table 12. Effects of a Korea-Mexico FTA on their economy

\begin{tabular}{l|r|r|r|r}
\hline \multirow{2}{*}{} & \multicolumn{2}{|c|}{$\begin{array}{c}\text { Short term, } \\
\text { complete competition }\end{array}$} & \multicolumn{2}{c}{$\begin{array}{c}\text { Mid to long term, } \\
\text { complete competition }\end{array}$} \\
\cline { 2 - 5 } & Korea & Mexico & Korea & \multicolumn{1}{c}{ Mexico } \\
\hline \hline Real GDP change (\%) & 0.01 & 0.02 & 0.03 & 0.15 \\
\hline Welfare change (\%) & 0.06 & 0.03 & 0.04 & 0.13 \\
\hline Welfare change (\$million) & 232.15 & 93.32 & 172.33 & 441.28 \\
\hline Exports increase to the world (\$million) & 208.92 & 80.63 & 522.30 & 311.02 \\
\hline
\end{tabular}

Source : KIEP

${ }^{8}$ See Inkyo Cheong, "The feasibilities and economic effects of a Korea-Mexico FTA," Seoul: KIEP, 2003. 
It is expected that the Korea-Mexico FTA would increase Korea's export of manufacturing goods, such as electric and electronic goods, machinery, textiles, motor vehicles and parts. Exports of some processed foods, agricultural products and fishery to Mexico are also expected to increase. On the other hand, the report says that the most promising items, among Mexico's exporting products to Korea that would increase due to the FTA are agricultural products and processed foods. Especially, Mexico's exports of vegetables, fruits and meat are expected to expand. More specifically, it is highly likely that Mexico's red peppers, onions, pork, grapes, watermelon, melons, garlic, beef, and oranges would compete with Korea's in the Korean market. ${ }^{9}$

From Mexico's point of view, a FTA with Korea could contribute to improving Mexico's welfare through elimination of trade diversion effects. In other words, Mexico, which has concluded FTAs with more than 30 countries, cannot help importing products from FTA counterparts, even if they are sometimes more expensive than those from Korea. Therefore, a Korea-Mexico FTA would remove such trade diversion effects and could result in a welfare gain for Mexico.

\section{The private sectors' position in Korea and Mexico}

In Latin America, Mexico, against which Korea records a trade surplus of about 2 billion dollars annually, is the most important market for Korea. Therefore, Korean companies have expressed their strong interest in the Mexican market and there is strong support for the conclusion of a Korea-Mexico FTA as more and more obstacles and difficulties for Korean exporters and companies operating in Mexico rise to the surface. According to a survey of prior FTA candidates, $78.4 \%$ of 295 companies that export more than 1 million dollars a year chose Mexico as Korea's FTA candidate. Moreover, Korean companies, who are concerned that Japanese companies might overwhelm them in Mexico, as a result of the Mexico-Japan FTA, hope that discussion on the Korea-Mexico FTA would be initiated as soon as possible.

\section{Tasks to promote a Korea-Mexico FTA}

Under these circumstances, the first task to achieve a Korea-Mexico FTA is to expand the relationship between the two countries' private sectors. It is very important to develop and facilitate promising areas where the two countries can cooperate in order to provide an amicable environment for economic relationships and integration among private sectors, which would help to initiate a formal discussion on the FTA. In this regard, the IT sector could be a good candidate for cooperation. The IT industry in Mexico is the largest and the most developed in Latin America and thus, IT companies in the two countries could cooperate in the area of technology and software development. Mexico could take advantage of this cooperative relationship when it enters IT markets in Latin America. 
Secondly, some ways to solve the trade imbalance between Korea and Mexico that I mentioned earlier would have to be provided. Since Mexico is concerned that this imbalance might be exacerbated as a result of the Korea-Mexico FTA, Korea should present some possibilities of Mexico's export increase toward Korea. For example, seasoned squid is one that secures the top position among imported goods from Mexico to Korea. Since Korea is the only country which imports seasoned squid and Mexican exporters of this product are operating on a very small scale, the Mexican government is very interested in supporting this sector. Therefore, Korea's efforts to inform that exports of some agricultural and fishery products like seasoned squid would increase with the Korea-Mexico FTA could trigger local Mexican governments' as well as the central government's support for it.

In addition, Mexico's coffee exports to Korea, which is now on the decrease, could rise again if it were imported duty-free through the FTA. Now imports of tropical fruits produced in Mexico are banned in Korea due to quarantine regulations, but the FTA could eliminate this measure and thus, Mexican tropical fruits could knock on the door of the Korean market.

It is also important for Korea to give a message that Korea's investment in Mexico could be expanded on a large scale. Indeed, Mexico, which has concluded FTAs with major trade partners, is now interested more in attracting foreign investment rather than expanding its exports through further FTAs. In this regard, we could relate Korean companies' investment plans in Mexico with the Korea-Mexico FTA. Since Mexico is adjacent to the USA, which is Korea's biggest trade partner, and their markets are open to each other through NAFTA, Mexico is considered to be the most appropriate FTA candidate for Korea. Moreover, Mexico would be the threshold for Korea to enter into Latin American markets. This means that Korea would consider Mexico as a more attractive subject for investment if the Korea-Mexico FTA becomes effective.

The Korea-Mexico FTA is also important to Mexico, for Korea would be the threshold for Mexico to access East Asia. Mexico, which has already completed FTAs with major countries in America and Europe, will have built an FTA network in Asia as well, as the Mexico-Japan FTA comes into effect. It is said that Mexico's next target is China. However, even for Mexico, China is not an easy partner because it is probable that the low-price manufactured goods and agricultural products of China would surge into the Mexican market. Before a Mexico-China FTA, Mexico is required to strengthen the competitiveness of its own industries. In this regard, the Korea-Mexico FTA could help to support small-scale agricultural and fishery exporters in Mexico and provide large-scale investment which would contribute to enhancing Mexican industries.

In addition, Mexico could achieve better access to China by taking advantage of Korea's geographical location. If Korea concludes an FTA with China before Mexico does, the Korea-Mexico FTA would become more fruitful to Mexico.

In short, in order to facilitate the Korea-Mexico FTA, the relationship and cooperation between the private sectors in the two countries should be expanded further before a formal discussion is initiated. It is also required to develop some ways to solve the trade imbalance between the two countries and to expand Korea's 
investment in Mexico. It is desirable for the two countries to begin FTA talks based on this kind of win-win strategy.

\section{REFERENCES}

\section{$<$ Books and Papers $>$}

Cheong, Inkyo, "The feasibilities and economic effects of a Korea-Mexico FTA," Seoul: KIEP, 2003.

Huh, Duck-jin, "The expected effects of a Mexico-Japan FTA on Korean exporters," in Trade Report(March), Seoul: KITA, 2004.

KOTRA, NAFTA and Korea's Responses, Seoul: KOTRA, 1994.

OECD, Economic Outlook 2002, June, 2002.

Song, Byung-tae, Joon-kyu Kim, Chul-hwan Do and Kyu-sun Choi, NAFTA's effects by industry and our strategies, Seoul: Deawoo Research Institute, 1993.

\section{$<$ Websites and other statistical data $>$}

Daewoo Electronics: www.dwe.co.kr

Korea International Trade Association: www.kita.net

KOTRA: www.kotra.or.kr

Ministry of Commerce, Industry and Energy: www.mocie.go.kr

Samsung Electronics: www.sec.co.kr

The Export-Import Bank of Korea: www.koreaexim.go.kr

Trade News, http://tradenews.net

UNCTAD, Personal Computer Trade Analysis System(PC-TAS) CD-ROM (1998-2002) 